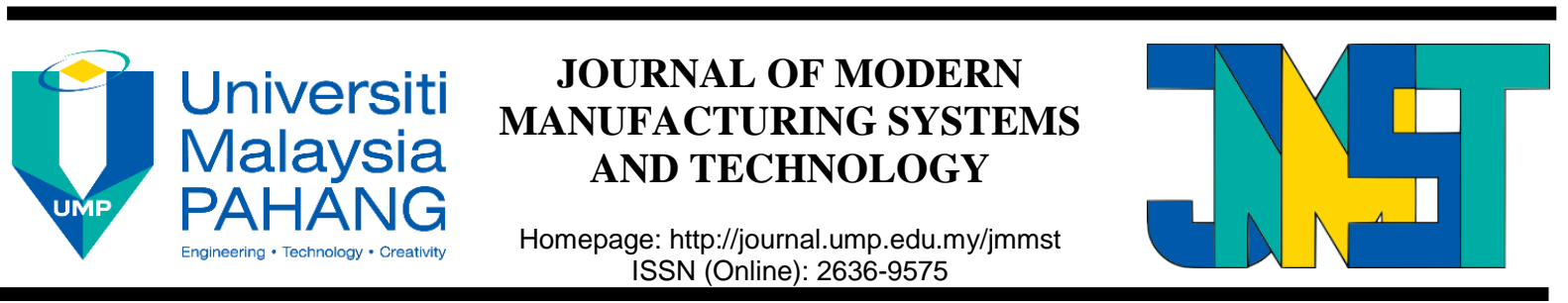

\title{
Integration of Mahalanobis-Taguchi System and activity based costing for remanufacturing decision
}

\author{
Nik Nurharyantie Nik Mohd Kamil ${ }^{1 *}$ and Mohd Yazid Abu ${ }^{1+}$
}

\begin{tabular}{|c|c|}
\hline *Correspondence & ABSTRACT \\
\hline $\begin{array}{l}\text { niknurharyantie@gmail.com } \\
\text { +This author contributes } \\
\text { equally to this work }\end{array}$ & $\begin{array}{l}\text { Remanufacturing is a process that returns the second hand and used product that have the } \\
\text { performance similar or better than the new product. The remanufacturer cannot be } \\
\text { predicting the end of life (EOL) of crankshaft to remanufacture, repair or reject due to the }\end{array}$ \\
\hline $\begin{array}{l}{ }^{1} \text { Faculty of Manufacturing } \\
\text { Engineering, Universiti } \\
\text { Malaysia Pahang, 26600, } \\
\text { Pekan, Pahang, Malaysia }\end{array}$ & $\begin{array}{l}\text { limited information provided by Original Equipment Manufacturer (OEM) which depend on a } \\
\text { traditional inspection to make a decision. Subsequently, Traditional Cost Accounting (TCA) } \\
\text { which the manufacturing overhead are driven by the production volume are being applied. }\end{array}$ \\
\hline $\begin{array}{l}\text { Articles Info: } \\
\text { Received } 11 \text { June } 2018 \\
\text { Received in revised form } \\
24 \text { Jul } 2018 \\
\text { Accepted } 11 \text { Sept } 2018 \\
\text { Available Online } 13 \text { Sept } \\
2018\end{array}$ & $\begin{array}{l}\text { The aim of this work is to develop a distinctive pattern of crankshaft and identify the critical } \\
\text { and non-critical parameter of crankshaft based on the Mahalanobis Taguchi System (MTS), } \\
\text { then applied the Activity Based Costing ( } A B C \text { ) as a method of estimation for the } \\
\text { remanufacturing cost of crankshaft. In methodology, the scatter diagram is construct to } \\
\text { develop the pattern recognition using T Method-3, Taguchi orthogonal array (OA) are } \\
\text { applied to identify the important parameter using T Method and lastly, the ABC system is }\end{array}$ \\
\hline $\begin{array}{l}\text { Keywords: } \\
\text { Remanufacturing; } \\
\text { mahalanobis taguchi } \\
\text { system; traditional cost } \\
\text { accounting; activity } \\
\text { based costing. }\end{array}$ & $\begin{array}{l}\text { analysed the costing of critical parameters. Quality inspection is the most important in quality } \\
\text { inspection to reduce the number of parameter of each engine model and to compare which } \\
\text { costing system can produce the cheapest price. Therefore, it is also to prove the combination } \\
\text { of applying MTS method with ABC system will make the profitability and manufacturing cost } \\
\text { are more accurate. }\end{array}$ \\
\hline
\end{tabular}

\section{INTRODUCTION}

The Great Depression in the 1930 at USA can be used as a term for remanufacturing [1] and from the past years usually has received increasing attention in the world. The percentage for increasing the number of yearly published scientific paper is $166 \%$ during the year 2009 to 2014; the triplication was found the CIRP community at the same time. There is long tradition of remanufacturing which are capital intensive and life expectancy [2]. Besides, this tradition can be achieved where the average cost reduction is lower than average cost new production which is 45 to $65 \%$. The concept of remanufacturing can be described by USIT, 2012 when the end-of-life (EOL) is restore by industrial process to be good same as original working. In globally, remanufacturing is widely used in sector automotive and auto parts, heavy earth movers, pumps, compressor, turbines, rail industry, aerospace and aircraft. All this part in these sectors get worn out during operations and eventually half of this part are static stationary supporting parts. So that, the remanufacturing process has five phases which are disassembly, inspection, cleaning and refurbishing, assembly and final testing [3]. However, when the product is disassembled, before worn out the parts, those must be clean and examine. So it can be decided a decision either to replace a new parts or 
refurbished. In addition, the remanufacturing is not only give profit for all company and business, but also for the environment and customers. The advantages for remanufacturing concept are this concept must provide a cheapest price of product quality than a product which is not remanufactured, less using raw materials, reduce waste and also high financial saving. Remanufacturing can save up to $85 \%$ raw materials, the consumption of electrical and thermal energy can reduce by 60 to $85 \%$, less water is used by $90 \%$ and also the greenhouse gas emission can be avoided according. It is also reduced the impact of environmental considerably.

Mahalanobis-Taguchi System (MTS) is a method to collect the diagnosis of behaviour pattern and forecast corresponding to sets multivariate patterns that proposed by Genichi Taguchi. Hence, the class imbalance problem will be resolved and the data distribution is not effected. The Orthogonal arrays (OA) and signal-to-noise ratios (SN) is used to consolidate from many parameters into a single group [4]. The application of MTS has been reported in decision making [5], green manufacturing [6], computational [7] and green technologies [8]. [9] Presented an effect of MTS on inspection time in electronics industry for flip-chip bumping height inspection.

Activity Based Costing (ABC) is develop during the last span of addressing the flaws of the traditional cost accounting (TCA) method [10] which only assigns costs to product based on an average overhead rate. Cost of manufacturing a product according to the activities needed to produce the item also is allocated by $A B C$ system. There are many applications of $A B C$ have been reported which are in supply chain, transportation, organizational, hospital, decision making, cellular manufacturing, radiotherapy, farm management and also in numerous energy and environmental issues such as product-mix decision models, product ecological footprint, and green airline fleet planning. According work performed by [11], the 0-1 mixed integer programming has used the ABC system and life cycle assessment (LCA) which assign resources and funding for energy saving activities to each green building through appropriate the cost driver. Hence, [12] LCA is same with ABC system which proposed the cost estimation of safety by using activity of risk assessment for the initial stages of construction since the major problem in the construction industry is the fatal construction accidents.

\section{METHODOLOGY}

This research is will focus on the crankpin journal that acts as a big role to change the motion of reciprocate to the motion of rotation. The amount of crankpin samples are needed for two engine model; Man and MTU183 with their limitation of remanufacturable tolerances that has analysed in Table 2.1.

Table 2.1: Collection data of crankpin

\begin{tabular}{|c|c|c|c|}
\hline Engine model & $\begin{array}{c}\text { No. of } \\
\text { sample }\end{array}$ & \multicolumn{2}{|c|}{$\begin{array}{c}\text { Remanufacturable tolerance } \\
\text { provided by OEM (mm) }\end{array}$} \\
\cline { 3 - 4 } & & Lower limit & Upper limit \\
\hline MTU183 & 15 & 113.980 & 114.000 \\
\hline Man & 15 & 112.0200 & 112.0400 \\
\hline
\end{tabular}

\section{Pattern Recognition}

The T Method is a sub-method of MTS for pattern recognition. The T Method-3 is the T Method that has the ability to classify objects into two categories which one is inside and another one is outside the unit space. The one is inside means the unit data or reference space and the outside the unit space means signal data. T method-3 starts with defined the unit data and computation of the average value of each parameter, where the unit data are selected based on their highest number of samples among other samples.

$$
\begin{gathered}
\text { Linear equation, } L_{1}=\bar{x}_{1} x_{11}+\bar{x}_{2} x_{22}+\cdots+\bar{x}_{k} x_{1 k} \\
\text { Effective divider, } \mathrm{r}=\bar{x}_{1}^{2}+\bar{x}_{2}^{2}+\cdots+\bar{x}_{k}^{2} \\
\text { Sensitivity, } \beta_{1}=\frac{L_{1}}{r}
\end{gathered}
$$

The sensitivity, indicates the gradient of incline that is shown in straight line. So that, it can conclude when the ascending the line to the right indicates that the $\mathrm{L}$ is positives, whereas descending the line to the right indicates that the $\mathrm{L}$ is negative.

$$
\text { Total variations, } S_{T 1}=x_{11}^{2}+x_{12}^{2}+\cdots+x_{1 k}^{2}
$$




$$
\begin{gathered}
\text { Variation of proportional term, } S_{\beta 1}=\frac{L_{1}^{2}}{r} \\
\text { Error variation, } S_{e l}=S_{T 1}-S_{\beta 1} \\
\text { Error variance, } V_{e l}=\frac{S_{e l}}{k-1} \\
\text { Standard SN Ratio, } \eta_{1}=\frac{1}{V_{e l}}
\end{gathered}
$$

When the value of $\eta$ is higher, the relationship between input and output will become stronger. Based on Equation 8 that calculate the SN ratio, it is show the standard signal to control the average value in the unit space; $r$ is represent the dividend but the numeral one has been chosen because it is frequently to all members.

$$
\begin{gathered}
Y_{i 1}=\beta_{i} \\
Y_{i 2}=\frac{1}{\sqrt{\eta_{i}}}=\sqrt{V_{e i}}
\end{gathered}
$$

The value of $Y_{1}$ can get directly from the value $\beta$ and $Y_{2}$ can be calculated as show in Equation 10. The average of $Y_{1}$ and $Y_{2}$ for prediction of unit data origin.

$$
\begin{aligned}
& \bar{Y}_{1}=\frac{1}{n}\left(Y_{11}+Y_{21}+\cdots+Y_{n 1}\right) \\
& \bar{Y}_{2}=\frac{1}{n}\left(Y_{12}+Y_{22}+\cdots+Y_{n 2}\right)
\end{aligned}
$$

The Mahalanobis Distance (MD) can be calculated by using Equation 13 below. When the A value is non-negative, so that the value of MD is always come out with zero or positive value.

$$
\text { Mahalanobis Distance, } D^{2}=\frac{Y A Y^{T}}{k}
$$

Unit data has highest samples number compared to signal data. To calculate the signal data it is similar method as a unit data has the same method but the value of $r$ and average parameter are exactly from the unit data.

\section{Parameter Evaluation}

T Method 1 is a sub-method of MTS for parameter evaluation. It is functionally to analyze the importance of any variables against the output. So that, in the previous sub-topic there are 6 crankpin diameter and MD which is generated will be used as input and output. By using T Method-1, there is no relationship among engine model and each engine model are evaluated separately. To apply this method, it is important to ensure that the data is normal or densely populated in the medium range by constructing a histogram. The highest sample will be defined as a unit data while remaining number of samples will be defined as signal data.

$$
\begin{gathered}
\bar{x}_{\mathrm{j}}=\frac{1}{n}\left(x_{1 j}+x_{2 j}+\cdots+x_{n j}\right) \\
\bar{y}=M_{0}=\frac{1}{n}\left(y_{1}+y_{2}+\cdots+y_{n}\right)
\end{gathered}
$$

The remaining sample of unit data is signal data. Signal data is normalized by using the average values of parameter and the output values of samples in the unit data. The purpose using normalization because to make the data more accurate and flexible by eliminating the redundancy. So that, normalization can perform by using Equation 16 and Equation 17. Table 2.2 is shown below is data for normalize signal data.

$$
\begin{aligned}
& X_{i j}=x_{i j}^{\prime}-\bar{x}_{j} \\
& M_{i}=y_{i}^{\prime}-M_{0}
\end{aligned}
$$

Table 2.2: Normalized signal data

\begin{tabular}{|c|c|c|c|c|c|}
\hline Data & 1 & 2 & $\ldots$ & $\mathrm{k}$ & Output value \\
\hline 1 & $X_{11}$ & $X_{12}$ & $\ldots$ & $X_{1 k}$ & $M_{1}$ \\
\hline 2 & $X_{21}$ & $X_{22}$ & $\ldots$ & $X_{2 k}$ & $M_{2}$ \\
\hline
\end{tabular}




\begin{tabular}{|c|c|c|c|c|c|}
\hline$\ldots$ & $\ldots$ & $\ldots$ & $\ldots$ & $\ldots$ & $\ldots$ \\
\hline$l$ & $X_{l 1}$ & $X_{l 2}$ & $\ldots$ & $X_{l k}$ & $M_{l}$ \\
\hline
\end{tabular}

$$
\begin{gathered}
\text { Proportional coefficient } \beta_{1}=\frac{M_{1} X_{11}+M_{2} X_{21}+\cdots+M_{l} X_{l 1}}{r} \\
\text { SN ratio } \eta_{1}=\left\{\frac{\frac{1}{r}\left(s_{\beta 1}-V_{1}\right)}{V_{e 1}}\left(\text { when } S_{\beta 1}>V_{e 1}\right)\right. \\
\quad\left(\text { when } S_{\beta 1} \leq V_{e 1}\right)
\end{gathered}
$$

When the output value of proportional coefficient, $\beta$ shown the positive value, it is indicating the gradient is ascending to the right but if the value of $\beta$ negative, it is shown the gradient is descending to the right. In basic study, the value of ? should be positive, but if the value is negative, automatically turns to zero. It means the relationship between input and output is no longer significant. Table 2.3 shows the results of proportional coefficient and SN ratio items by item.

Table 2.3: Proportional coefficient and SN ratio items by item

\begin{tabular}{|c|c|c|c|c|}
\hline \multirow{2}{*}{$\beta, \eta$} & \multicolumn{4}{|c|}{ Item/Variable } \\
\cline { 2 - 5 } & 1 & 2 & $\ldots$ & $\mathrm{k}$ \\
\hline Proportional $\beta$ & $\beta_{1}$ & $\beta_{2}$ & $\ldots$ & $\beta_{k}$ \\
\hline SN ratio $\eta$ & $\eta_{1}$ & $\eta_{2}$ & $\ldots$ & $\eta_{k}$ \\
\hline
\end{tabular}

An integrated result is obtained by weighting it with SN ratio, which is the estimated measure of precision of each parameter. Thus, the integrated estimated value of the signal data can be calculated as Equation 25. Table 2.4 shows the measured values and integrated estimated values.

$\underline{\text { Table 2.4: Measured values and integrated estimated values of signal data }}$

\begin{tabular}{ccc}
\hline Data No & Measured value & Integrated Estimate Value \\
\hline 1 & $M_{1}$ & $\widehat{M}_{1}$ \\
\hline 2 & $M_{2}$ & $\widehat{M}_{2}$ \\
\hline$:$ & $:$ & $:$ \\
\hline$:$ & $:$ & $:$ \\
\hline$l$ & $M_{l}$ & $\widehat{M}_{l}$ \\
\hline
\end{tabular}

Integrated Estimate value $\widehat{M}_{\mathrm{i}}=\frac{\eta_{1} \times \frac{X_{i 1}}{\beta_{1}}+\eta_{2} \times \frac{X_{i 2}}{\beta_{2}}+\cdots+\eta_{k} \times \frac{X_{i k}}{\beta_{k}}}{\eta_{1}+\eta_{2}+\cdots+\eta_{k}}$

The Equation 26 must be based on suitability of orthogonal array.

$$
\begin{gathered}
\text { Integrated Estimate SN Ratio } \eta=10 \log \left(\frac{\frac{1}{r}\left(S_{\beta}-V_{e}\right)}{V_{e}}\right) \\
\text { Linear equation } \mathrm{L}=M_{1} \widehat{M}_{1}+M_{2} \widehat{M}_{2}+\cdots+M_{l} \widehat{M}_{l} \\
\text { Effective divider } \mathrm{r}=M_{1}^{2}+M_{2}^{2}+\cdots+M_{l}^{2} \\
\text { Total variation } S_{T}=\widehat{M}_{1}^{2}+\widehat{M}_{2}^{2}+\ldots+\widehat{M}_{l}^{2} \\
\text { Variation of proportional term } S_{\beta}=\frac{L^{2}}{r} \\
\text { Error variation } S_{e}=S_{T}-S_{\beta} \\
\text { Error variance } V_{e}=\frac{S_{e}}{l-1}
\end{gathered}
$$

There are two level $\mathrm{L}_{12}$ orthogonal array consists of level 1 and level 2 . The level one means 1 is the item that will be used whereas level two is the item that will not be used. In relation to the factorial effect graph, descending the line from left to right indicates that parameter has an effect of elevating the output. It means the larger value of SN ratio it is considered used but the smaller SN ratio it is considered 
not used for parameter. When the degree of contribution turns to be positive so that the parameter is classified as critical. Otherwise, ascending the line from left to right indicates that the parameter has an effect of lowering the output.

\section{Activity Based Costing}

Before this, the critical parameter which had analysed in previous had used MTS evaluation technique that is integrate with the $\mathrm{ABC}$ system that is consider the issue of the volume-based change to an activity-based cost driver. The number of overhead categorized is larger from the beginning will give the closed exact value of the overhead apportionment whereby the remanufacturing cost is closer to an accurate value when the number of activities centre is larger. Since overhead apportionment based on the number of activities is more accurate, the final remanufacturing cost is probable to acquire a better estimation even though the different of complexity for each engine model. In addition, the ABC system has a tendency to enhance control over overhead cost because product diversity has different activities required to perform it.

\section{RESULT AND DISCUSSION}

\section{Pattern Recognition}

Scatter diagram is used to classify the engine model from the EOL crankshaft into recovery operation. There are three classification of crankshaft which are remanufactured, repair, or reject. The total value of remanufacturable tolerance generates the larger of the values of MD. OEM provides the larger tolerance of remanufacturable and it is closer to the maximum remanufacturable tolerance. Otherwise, when the smaller MD is generated, it will give the larger the total value of rejected tolerance that acquired to the minimum tolerances provided by OEM. The highest number of samples can be considered by unit data and the remaining of engine models can be considered by signal data.

\section{MTU183 Engine}

The scatter diagram of Figure 4.1 shows the relationship between two variables which are $\mathrm{Y}_{1}$ and $\mathrm{Y}_{2}$ of MTU 183 engine model. The blue distribution is indicating the remanufacturable group, the orange distribution is indicating the repairable group whereby the black distribution is indicating the rejected group. Based on the Figure 3.1, the scatter diagram can be described the goodness of fit or the badness of fit of the linear model which is depend on coefficient of correlation, $r$. The value of $r$ is 0.80250591 which is indicate positive correlation. So, it means the closer value of $r$ to 1.00 , the better is the fit, with a value of 1 meaning that all point falls on the line.

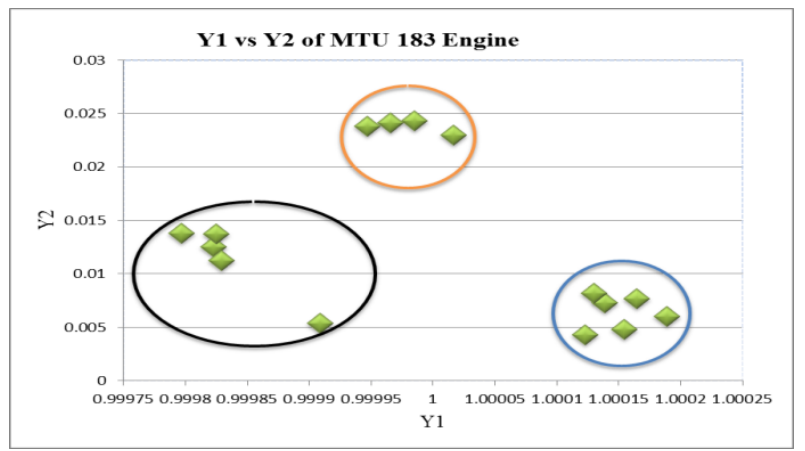

Figure 3.1: Scatter diagram of MTU 183 engine model.

Man Engine

The scatter diagram of Figure 3.2 shows the relationship between two variables which are $\mathrm{Y}_{1}$ and $\mathrm{Y}_{2}$ of MAN engine model. The green distribution is indicating the repairable group whereby the red distribution is indicating the remanufacturable group. The value of $r$ for the Man engine model also show the positive value which is 0.253406287 which indicate the positive correlation. 


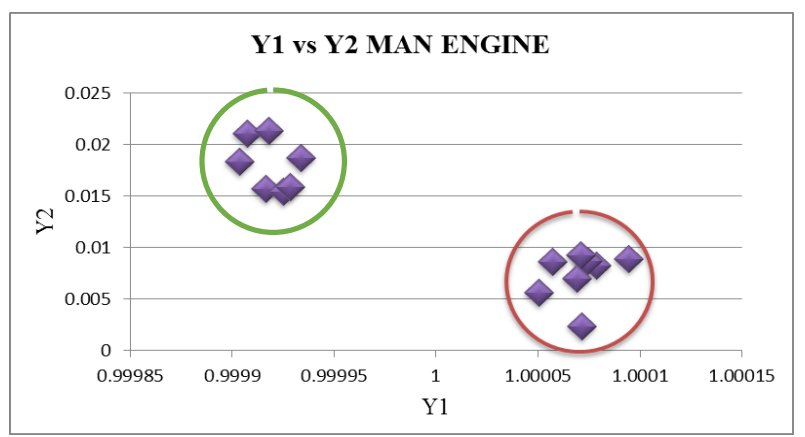

Figure 3.2: Scatter diagram of Man engine model.

\section{Parameter Evaluation}

The Taguchi's array method is used to measure and evaluate the critical and non-critical parameter crankpin of crankshaft for both remanufacturable engine model which are MTU183 and Man. According to the factorial effect, the higher SN ratio of parameter crankshaft in used (Level 1) indicates the higher the positivity contribution degree of parameter. Otherwise, the lower SN ratio of parameter is not used (Level 2) that indicates the lower the positivity contribution degree of parameter. Hence, the factorial effect graph in descending line from left to the right is indicates the parameter is significant and the crankshaft is critical. Thus, the quality of inspection will be improved when the number of parameter is reduced.

\section{MTU183 Engine}

Based on analysing of 15 samples of remanufacturable classification among 6 crankpin diameter of crankshaft, the parameter of crankshaft is evaluated. Figure 3.3 is illustrated the degree of contribution of MTU183 engine model. This engine has 2 critical and 4 non-critical parameters of crankpin. At look from the pattern, it is clear the crankpin diameter 4 shows the highest difference, followed by crankpin diameter $1,2,3$, and 5 . Therefore, the crankpin diameter 4 and 1 have been considered of critical crankpin.

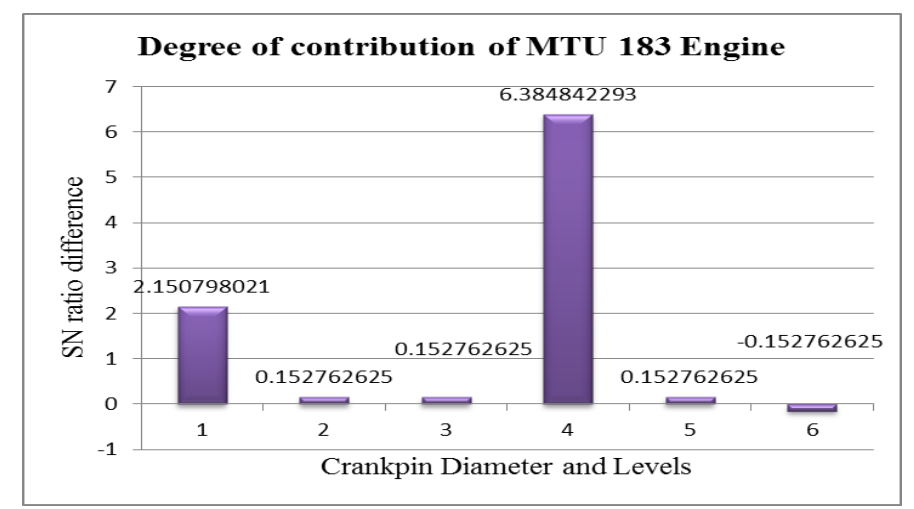

Figure 3.3: Evaluation importance through Degree of contribution of MTU 183 engine model.

\section{Man Engine}

Figure 3.4 is show the important parameter of the Man engine that has been analysed among 15 samples of remanufacturable and repairable groups. This engine model has 3 critical and 3 non-critical of parameter crankpin. So, the ranking is based on critically contribution which are 5, 2, 4, 1, 3, and 6 . 


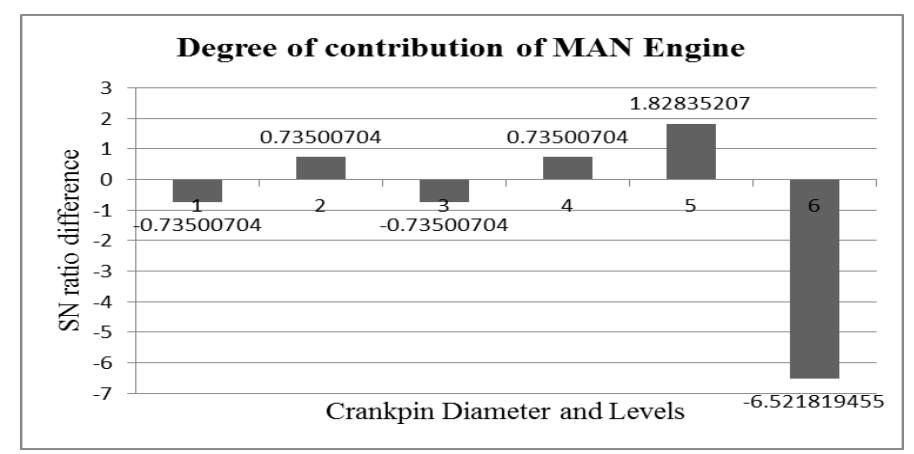

Figure 3.4: Evaluation importance through Degree of contribution of Man engine model.

\section{ABC system}

There are six department of apportionment of activities which are administration, factory management, quality control, remanufacturing, and sales and dispatch. The purpose of all activities is to produce the remanufactured crankshafts that are really affected to the industry's business. Table 3.1 is show all the centers with their activities that had been approved by the Head of Workshop.

Table 3.1: Centres with their activities.

\begin{tabular}{|l|l|l|}
\hline No & Centre & Activities \\
\hline 1 & Administration & $\begin{array}{l}\text { 1.Manage the accounts receivable / payable systems in order to ensure complete } \\
\text { and accurate recording of all monetary transections. } \\
\text { 2.Ensure accurate payment of benefits and allowances with respect to the } \\
\text { preparation of payrolls. }\end{array}$ \\
\hline 2 & Corporate management & $\begin{array}{l}\text { 1.Acquire sufficient resources for the organization's operations. } \\
\text { 2. Provide continuity for the organization by setting up a corporate and legal } \\
\text { framework. }\end{array}$ \\
\hline 3 & Factory management & $\begin{array}{l}\text { 1.Provide worker schedule efficiently in order to ensure running productions meet } \\
\text { the targets. } \\
\text { 2. Implement the factory manufacturing strategic plans by estimating the quantity } \\
\text { of machines, tools, and transportation. }\end{array}$ \\
\hline 4 & Quality control & $\begin{array}{l}\text { 1. Maintain record pertaining to inspection on all tools and equipment. } \\
\text { 2. Record the crankpin diameter and crankshaft hardness. }\end{array}$ \\
\hline 5 & Remanufacturing & $\begin{array}{l}\text { 1. Grinding, polishing and cleaning operation performed according to the } \\
\text { standards provided by OEM. }\end{array}$ \\
\hline 6 & Sales and Dispatch & $\begin{array}{l}\text { 1. Manage sales and order account. } \\
\text { 2. Prepare packaging plans prior to dispatching the crankshafts. }\end{array}$ \\
\hline
\end{tabular}

Resource cost are assign to activity centres which is six departments with allocate the amount of MYR137000 for crankshaft by the corporate management department, administration, factory management, quality control, remanufacturing, and sales and dispatch. There are two types of cost which are direct and indirect costs are covered by overhead category by each department. These types of costs are covered including wages, depreciation, consumables, energy, building and other costs. Table 3.2 clearly show that the apportionment of overhead of each department be more accurate when the number of department and overhead categories is larger.

Table 3.2: Assigning resources cost to centres

\begin{tabular}{|c|c|c|c|c|c|c|}
\hline \multirow{3}{*}{$\begin{array}{c}\text { Overhead } \\
\text { category }\end{array}$} & \multicolumn{6}{|c|}{ Activity centre } \\
\hline & \multicolumn{2}{|c|}{$\begin{array}{c}\text { Administration } \\
(17 \%)\end{array}$} & \multicolumn{2}{|c|}{$\begin{array}{c}\text { Corporate } \\
\text { management } \\
(19 \%)\end{array}$} & \multicolumn{2}{|c|}{$\begin{array}{c}\text { Factory } \\
\text { management } \\
(11 \%)\end{array}$} \\
\hline & $72 \%$ & 16768.8 & $63 \%$ & 16398.9 & $68 \%$ & 10247.6 \\
\hline Depreciation & $4 \%$ & 931.60 & $3 \%$ & 780.90 & $3 \%$ & 452.10 \\
\hline Consumables & $2 \%$ & 465.80 & $0 \%$ & 0 & $0 \%$ & 0 \\
\hline Energy & $8 \%$ & 1863.20 & $3 \%$ & 780.90 & $4 \%$ & 602.80 \\
\hline Building cost & $7 \%$ & 1630.30 & $5 \%$ & 1301.50 & $5 \%$ & 753.50 \\
\hline Other cost & $7 \%$ & 1630.30 & $26 \%$ & 6767.80 & $20 \%$ & 3014.00 \\
\hline Total (MYR) & & 23290.00 & & 26030.00 & & 15070.00 \\
\hline
\end{tabular}




\begin{tabular}{|c|c|c|c|c|c|c|c|}
\hline \multirow{3}{*}{$\begin{array}{c}\begin{array}{l}\text { Overhead } \\
\text { category }\end{array} \\
\text { Wages }\end{array}$} & \multicolumn{6}{|c|}{ Activity centre } & \\
\hline & \multicolumn{2}{|c|}{$\begin{array}{c}\text { Quality control } \\
(19 \%)\end{array}$} & \multicolumn{2}{|c|}{$\begin{array}{c}\text { Remanufacturing } \\
(26 \%)\end{array}$} & \multicolumn{2}{|c|}{$\begin{array}{c}\text { Sales and } \\
\text { Dispatch } \\
(8 \%)\end{array}$} & \\
\hline & $63 \%$ & 16398.9 & $46 \%$ & 16385.2 & $55 \%$ & 6028.00 & \\
\hline Depreciation & $8 \%$ & 2082.40 & $21 \%$ & 7480.20 & $3 \%$ & 328.80 & \\
\hline Consumables & $0 \%$ & 0 & $6 \%$ & 2137.20 & $1 \%$ & 109.60 & \\
\hline Energy & $2 \%$ & 520.60 & $7 \%$ & 2493.40 & $4 \%$ & 438.40 & \\
\hline Building cost & $3 \%$ & 780.90 & $1 \%$ & 356.20 & $3 \%$ & 328.80 & \\
\hline Other cost & $24 \%$ & 6147.20 & $19 \%$ & 6767.80 & $33 \%$ & 3616.80 & \\
\hline Total (MYR) & & 26030.00 & & 35620.00 & & 10960.00 & \\
\hline $\begin{array}{l}\text { Grand Total } \\
\text { (MYR) }\end{array}$ & & & & & & & $137,000.00$ \\
\hline
\end{tabular}

Based on Table 3.2, the highest apportion of overhead is remanufacturing department that belong percentage of $26 \%$ among others department percentage. The total of remanufacturing cost is MYR 35620 that allocates the amount of MYR16,385.20 for overhead category of wages. It is to produce the crankshaft that the centre has 1 leader, 2 workers for cleaning process and 4 workers for the grinding and polishing with their compensation rate is approximately MYR900, MYR450, and MYR400 respectively per month. Telephones, printers, air conditioners, computers, can be categorized into depreciation that allocate approximately MYR7480.20 since this department has work area in both inside and outside the office. Grinding, polishing and cleaning machines maintenance is approximately MYR15000 while maintenance for tool setup is MYR5000. The total of the consumables is MYR2137.20 with respect to the documentation (MYR2.10 per pack *5 unit*12month), renewal formal workers appearance (MYR2.30*7 workers), stone grinder (MYR680. per year), grid paper (MYR401.65 per year), detergent for cleaning process (MYR800.00), safety shoes (MYR2.40*7) and tissue (MYR96.65 per year). The department uses the energy usage with the total cost around MYR2493.40 which include the office (MYR61.78*12), grinding machines (MYR57*12), polishing machine (MYR37.00*12) and cleaning machine (MYR52*12). The total of the building cost is MYR356.20 including the renovations and approximately MYR6767.80 is provision from other costs such as training.

The remanufacturing activities such as grinding (34\%), polishing (30\%) and cleaning (36\%) as shown in Table 3.3 is determined from the reallocated of amount MYR35620.00 of the apportioned overhead for remanufacturing department from the Table 3.2.

Table 3.3: Assigning remanufacturing centre cost to activities

\begin{tabular}{|c|c|c|c|c|}
\hline \multirow[t]{2}{*}{ Overhead category } & \multicolumn{3}{|c|}{ Remanufacturing centre activities } & \\
\hline & $\begin{array}{c}\text { Grinding } \\
34 \%\end{array}$ & $\begin{array}{c}\text { Polishing } \\
30 \%\end{array}$ & $\begin{array}{c}\text { Cleaning } \\
36 \%\end{array}$ & \\
\hline Wages & 5667.85 & 5001.05 & 6001.26 & \\
\hline Depreciation & 2573.55 & 2270.78 & 2724.93 & \\
\hline Consumables & 885.30 & 781.15 & 937.38 & \\
\hline Energy & 799.31 & 705.28 & 846.33 & \\
\hline Building cost & 151.39 & 133.58 & 160.29 & \\
\hline Other cost & 2033.40 & 1794.18 & 2153.02 & \\
\hline Total (MYR) & 12110.80 & 10686.00 & 12823.20 & 35620.00 \\
\hline
\end{tabular}

According to the Table 3.3, grinding activity is a process wherein the crankpins are grinding according to the standards providing by the OEM, after that the grinding artifacts are removed by the polishing activity, while the potential harmful contaminants such as dust and debris from remanufacturing process are removed by the cleaning activity. The remanufacturing centre has a 1 head, 4 workers on grinding and polishing, and 2 workers for cleaning with their rates of MYR300, MYR150, and MYR140 respectively for grinding activity, MYR300, MYR150, and MYR140 respectively for polishing activity and MYR300, MYR155, and MYR148 respectively for cleaning activity. The depreciation such as air conditioners, computers, fax machines, telephones, printers and tools required for setup for servicing are allocated approximately MYR2573.55 (grinding), MYR2270.78 (polishing), and MYR2724.93 (cleaning). The total of the consumables is MYR885.30 (grinding), MYR781.15 (polishing), and MYR937.38 (cleaning) per year with respect to the papers, laser cartridge powder, coveralls, tissues, goggles, safety shoes, grid paper and detergents. Those grinding, polishing, and cleaning machines that utilize electricity are measured in kilowatts and allocated about MY799.31, MYR705.28 and MYR846.33 per year respectively. 
About MYR151.39 (grinding), MYR133.58 (polishing) and MYR160.29 (cleaning) apportioned to building cost for a better setup to make remanufacturing more efficient. The resource driver of other costs in grinding activity is the overtime of labor spent on the activity especially when expanding orders, meanwhile for the polishing and cleaning activity, the resource driver of other costs in those activities is the overtime of labor spent on the activity.

Activity driver can be explained by a cost driver that used to estimate the costs for an activity expended by the cost objects. The costs of the object will distort during selecting the activity drivers. Activity drivers can be more than one per activity. Table 3.4 show the cost per unit of activity driver that calculate and the estimation of the quantity of activity driver is obtained for each activity for the year.

Table 3.4: Activities and activity cost per unit of activity drivers

\begin{tabular}{|c|c|c|c|c|}
\hline Activity centre with activities & $\begin{array}{l}\text { Activity } \\
\text { cost (MYR) }\end{array}$ & Activity driver & $\begin{array}{l}\text { Predict quantity of activity } \\
\text { driver }\end{array}$ & $\begin{array}{l}\text { Cost per unit of } \\
\text { activity driver (MYR) }\end{array}$ \\
\hline \multicolumn{5}{|l|}{ Administration } \\
\hline Process receivables & 5550.00 & No. of invoices & 500 units & 11.10 \\
\hline Process payables & 6240.00 & No. of purchase orders & 475 units & 13.14 \\
\hline Operating IT system & 9000.00 & No. of CPU time-hours & 8760 hours & 1.03 \\
\hline \multirow[t]{2}{*}{ Preparing payroll } & 2500.00 & \multirow[t]{2}{*}{ No. of pay slips } & \multirow[t]{2}{*}{200 persons } & \multirow[t]{2}{*}{12.50} \\
\hline & 23290.00 & & & \\
\hline \multicolumn{5}{|l|}{ Corporate management } \\
\hline Providing continuity for organization & 6767.80 & None available & Facility activity & - \\
\hline Appointing a chief executive & 5986.90 & None available & Facility activity & - \\
\hline Governing the organization & 5206.00 & None available & Facility activity & - \\
\hline \multirow{2}{*}{$\begin{array}{l}\text { Acquiring resources for organization } \\
\text { operation }\end{array}$} & 8069.30 & \multirow[t]{2}{*}{ None available } & \multirow[t]{2}{*}{ Facility activity } & \multirow[t]{2}{*}{-} \\
\hline & 26030.00 & & & \\
\hline \multicolumn{5}{|l|}{ Factory management } \\
\hline Program production & 5070.00 & No. of man hours & 20000 hours & 0.25 \\
\hline \multirow[t]{4}{*}{ Expediting order } & 4300.00 & No. of grinding machines & 12 units & 89.58 \\
\hline & & No. of polishing machines & 12 units & 89.58 \\
\hline & & No. of cleaning machines & 11 units & 97.73 \\
\hline & & No. of man power & 12 persons & 89.58 \\
\hline Managing plant & 3700.00 & No. of crankshaft & 400 units & 9.25 \\
\hline \multirow{2}{*}{ Training production personnel } & 2000.00 & \multirow[t]{2}{*}{ No. of training-hours } & \multirow[t]{2}{*}{4500 units } & \multirow[t]{2}{*}{4.44} \\
\hline & 15070.00 & & & \\
\hline \multicolumn{5}{|l|}{ Quality control } \\
\hline Tools and equipment maintenance & 8000.00 & No. of tool-hours & 2500 hours & 3.20 \\
\hline Hardness measurement & 5200.00 & No. of crankshaft & 500 units & 10.40 \\
\hline Inspection process & 3500.00 & No. of crankpins & 2900 units & 1.21 \\
\hline Leak testing & 5100.00 & No .of testing hours & 4900 units & 1.04 \\
\hline \multirow[t]{2}{*}{ Training on quality } & 4230.00 & \multirow[t]{2}{*}{ No .of training hours } & \multirow[t]{2}{*}{800 units } & \multirow[t]{2}{*}{5.29} \\
\hline & 26030.00 & & & \\
\hline \multicolumn{5}{|l|}{ Remanufacturing } \\
\hline \multirow[t]{2}{*}{ Grinding } & 12110.80 & \multirow{7}{*}{$\begin{array}{l}\text { No. of machine hours } \\
\text { No. of setup hours } \\
\text { No. of machine hours } \\
\text { No. of setup hours } \\
\text { No. of machine hours } \\
\text { No. of setup hours }\end{array}$} & 9000 hours & 0.67 \\
\hline & & & 8320 hours & 0.73 \\
\hline Polishing & 10686.00 & & 9000 hours & 0.70 \\
\hline & & & 8320 hours & 0.53 \\
\hline \multirow{3}{*}{ Cleaning } & 12823.20 & & 3500 hours & 1.78 \\
\hline & & & 7500 hours & 0.88 \\
\hline & 35620.00 & & & \\
\hline Sales and Dispatch & & & & \\
\hline Process sales order & 2525.00 & & 175 units & 14.43 \\
\hline Packaging plan & 5700.00 & No. of man hours & 4800 hours & 1.19 \\
\hline Packaging training & 2735.00 & No. of training hours & 760 hours & 3.60 \\
\hline & 10960.00 & & & \\
\hline Total Cost & $137,000.00$ & & & \\
\hline
\end{tabular}

Based on the remanufacturing activities centre in the Table 3.4, the amount of activity cost of grinding is MYR12110.80 which means the longer the machine and setup hours, the larger the cost of grinding activity. Since the continuous of usage the grinding machines, it will cause the higher depreciation cost. Hence, the higher consumable costs is caused by using the protective personal equipment including safety shoes, coveralls, and goggles. For the activity cost of polishing, it shows the amount of MYR10686.00 which is less than the cost of grinding. The longer the machine and setup hours, the larger the cost of polishing. The higher depreciation cost is caused by the continuous of usage the polishing machine that is responsible to remove the excess metal on the surface of all the crankpins. The higher cost of remanufacturing is MYR12823.20 that indicates the cleaning cost. So, the longer machine setup hours, the larger cost of the cleaning activity. Therefore, the costs of depreciation and consumable are also increase as same the grinding and polishing machines. The energy cost is increased based on the usage of electricity of all the machines.

Referring to Table 3.5, a bill of activities is prepared for the MTU 183 engine model. This engine model is considering 15 units of crankshafts with 2 crankpins that are used. So, the crankshafts have an estimated cost of MYR687.90 per unit with remanufacturing and non-remanufacturing cost of MYR145.74 
and MYR542.22 respectively. This research keeps the similar unit of grinding, polishing, and cleaning machines of expediting order which is 2 to make a fair judgement for all those bills of engine model prepared.

Table 3.5: Activity -based product cost (MTU 183)

\begin{tabular}{|c|c|c|c|c|c|}
\hline $\begin{array}{l}\text { Activity } \\
\text { Level }\end{array}$ & Activity & $\begin{array}{l}\text { Cost per } \\
\text { unit of } \\
\text { activity } \\
\text { driver } \\
\text { (MYR) }\end{array}$ & $\begin{array}{l}\text { Annual quantity of } \\
\text { cost driver } \\
\text { consumed }\end{array}$ & $\begin{array}{c}\text { Annual cost } \\
\text { (MYR) }\end{array}$ & $\begin{array}{l}\text { Cost per unit of } \\
\text { product (MYR) }\end{array}$ \\
\hline Unit & Measure hardness & 10.40 & 15 units & 156.00 & \\
\hline Unit & Inspection process & 1.21 & 30 units & 36.30 & \\
\hline Unit & Grinding-machine hours & 0.67 & 75 hours & 50.25 & \\
\hline Unit & Grinding-setup hours & 0.73 & 135 hours & 98.55 & \\
\hline Unit & Polishing-machine hours & 0.70 & 30 hours & 21.00 & \\
\hline Unit & Polishing-setup hour & 0.53 & 120 hours & 63.60 & \\
\hline Unit & Cleaning-machine hours & 1.78 & 85 hours & 151.30 & \\
\hline Unit & Cleaning-setup hour & 0.88 & 100.4 hours & 88.36 & \\
\hline Unit & Perform leak testing & 1.04 & 70 hours & 72.80 & \\
\hline Unit & Polishing-machine hours & 0.70 & 30 hours & 21.00 & \\
\hline Batch & Program production & 0.25 & 1659.5 hours & 414.88 & \\
\hline Batch & Expedite order-grinding machines & 89.58 & 2 units & 179.16 & \\
\hline Batch & Expedite order-polishing machines & 89.58 & 2 units & 179.16 & \\
\hline Batch & Expedite order-cleaning machines & 97.73 & 2 units & 195.46 & \\
\hline Facility & Manage Plan & 9.25 & 15 units & 138.75 & \\
\hline \multicolumn{4}{|c|}{ Total remanufacturing activity cost } & 2186.31 & 145.74 \\
\hline Unit & Equipment maintenance & 3.20 & 49.5 hours & 158.40 & \\
\hline Batch & Process receivables & 11.10 & 150 units & 1665.00 & \\
\hline Batch & Process Payable & 13.14 & 150 units & 1971.00 & \\
\hline Batch & Operate IT system & 1.03 & 2112 hours & 2175.36 & \\
\hline Batch & Prepare payroll & 12.50 & 18 persons & 225.00 & \\
\hline Batch & Process sales order & 14.43 & 90 units & 1298.70 & \\
\hline Facility & Training production personnel & 4.44 & 48 hours & 213.12 & \\
\hline Facility & Training on quality & 5.29 & 48 hours & 253.92 & \\
\hline Facility & Packaging training & 3.60 & 48 hours & 100.80 & \\
\hline \multicolumn{4}{|c|}{ Total non-remanufacturing activity cost } & 8133.30 & 542.22 \\
\hline \multicolumn{4}{|c|}{ Total crankpin cost per unit } & & 687.90 \\
\hline
\end{tabular}

Referring to Table 3.6, a bill of activities is prepared for the Man engine model. This engine model is considering 15 units of crankshafts with 3 crankpins that are used. So, the crankshafts have an estimated cost of MYR731.40 per unit with remanufacturing and non-remanufacturing cost of MYR149.90 and MYR581.49 respectively. This research keeps the similar unit of grinding, polishing, and cleaning machines of expediting order which is 2 to make a fair judgement for all those bills of engine model prepared. Hence, this research is also maintaining the similar number of annual operating IT hour which is 2112 hour which is considered of work of 8 hours per day and 22 days per month.

Table 3.6: Activity -based product cost (MAN)

\begin{tabular}{|c|c|c|c|c|c|}
\hline $\begin{array}{l}\text { Activity } \\
\text { Level }\end{array}$ & Activity & $\begin{array}{c}\text { Cost per } \\
\text { unit of } \\
\text { activity } \\
\text { driver } \\
\text { (MYR) }\end{array}$ & $\begin{array}{c}\text { Annual quantity of } \\
\text { cost driver } \\
\text { consumed }\end{array}$ & $\begin{array}{l}\text { Annual cost } \\
\text { (MYR) }\end{array}$ & $\begin{array}{l}\text { Cost per unit of } \\
\text { product (MYR) }\end{array}$ \\
\hline Unit & Measure hardness & 10.40 & 15 units & 156.00 & \\
\hline Unit & Inspection process & 1.21 & 45 units & 54.45 & \\
\hline Unit & Grinding-machine hours & 0.67 & 102 hours & 68.34 & \\
\hline Unit & Grinding-setup hours & 0.73 & 156 hours & 113.88 & \\
\hline Unit & Polishing-machine hours & 0.70 & 52 hours & 36.40 & \\
\hline Unit & Polishing-setup hour & 0.53 & 142 hours & 75.26 & \\
\hline Unit & Cleaning-machine hours & 1.78 & 103.2 hours & 183.70 & \\
\hline Unit & Cleaning-setup hour & 0.88 & 114.6 hours & 100.85 & \\
\hline Unit & Perform leak testing & 1.04 & 92 hours & 95.68 & \\
\hline Unit & Polishing-machine hours & 1.19 & 73.4 hours & 87.35 & \\
\hline Batch & Program production & 0.25 & 1665.9 hours & 416.48 & \\
\hline Batch & Expedite order-grinding machines & 89.58 & 2 units & 179.16 & \\
\hline Batch & Expedite order-polishing machines & 89.58 & 2 units & 179.16 & \\
\hline Batch & Expedite order-cleaning machines & 97.73 & 2 units & 195.46 & \\
\hline Facility & Manage Plan & 89.58 & 3 persons & 268.74 & \\
\hline \multicolumn{4}{|c|}{ Total remanufacturing activity cost } & 2349.66 & 156.64 \\
\hline Unit & Equipment maintenance & 3.20 & 49.5 hours & 158.40 & \\
\hline Batch & Process receivables & 11.10 & 150 units & 1665.00 & \\
\hline
\end{tabular}




\begin{tabular}{|c|c|c|c|c|c|}
\hline Batch & Process Payable & 13.14 & 150 units & 1971.00 & \\
\hline Batch & Operate IT system & 1.03 & 2112 hours & 2175.36 & \\
\hline Batch & Prepare payroll & 12.50 & 18 persons & 225.00 & \\
\hline Batch & Process sales order & 14.43 & 90 units & 1298.70 & \\
\hline Facility & Training production personnel & 4.44 & 48 hours & 213.12 & \\
\hline Facility & Training on quality & 5.29 & 48 hours & 253.92 & \\
\hline Facility & Packaging training & 3.60 & 48 hours & 100.80 & \\
\hline \multicolumn{4}{|c|}{ Total non-remanufacturing activity cost } & 8722.40 & $\mathbf{5 8 1 . 4 9}$ \\
\hline \multicolumn{4}{|c|}{ Total crankpin cost per unit } & & 738.13 \\
\hline
\end{tabular}

Table 3.7 is show the cost per unit of crankshaft that belongs to MAN engine model. The remanufacturing cost of this engine model is MYR799.37 and non-remanufacturing cost of MYR217.88 and MYR581.49 respectively. There are altogether 15 units of crankshaft. The highest cost is spending in remanufacturing cost at program production is MYR664.75. This is because program production is the key section of the state plan in a target for the sale and production to achieve a certain quantity output.

Table 3.7: Cost by ABC system from traditional inspection (Man)

\begin{tabular}{|c|c|c|c|c|c|}
\hline $\begin{array}{l}\text { Activity } \\
\text { Level }\end{array}$ & Activity & $\begin{array}{l}\text { Cost per unit of } \\
\text { activity driver } \\
\text { (MYR) }\end{array}$ & $\begin{array}{l}\text { Annual quantity } \\
\text { of cost driver } \\
\text { consumed }\end{array}$ & $\begin{array}{l}\text { Annual cost } \\
\text { (MYR) }\end{array}$ & $\begin{array}{l}\text { Cost per unit } \\
\text { of product } \\
\text { (MYR) }\end{array}$ \\
\hline Unit & Measure hardness & 10.40 & 15 units & 156.00 & \\
\hline Unit & Grinding-machine hours & 0.67 & 195.4 hours & 130.92 & \\
\hline Unit & Grinding-setup hours & 0.73 & 255 hours & 186.15 & \\
\hline Unit & Polishing-machine hours & 0.70 & 100 hours & 70.00 & \\
\hline Unit & Cleaning-machine hours & 1.78 & 215 hours & 382.70 & \\
\hline Unit & Cleaning-setup hour & 0.88 & 220.4 hours & 193.95 & \\
\hline Unit & Perform leak testing & 1.04 & 180 hours & 187.20 & \\
\hline Unit & Polishing-machine hours & 1.19 & 65.5 hours & 77.95 & \\
\hline Batch & Program production & 0.25 & 2659 hours & 664.75 & \\
\hline Batch & Expedite order-grinding machines & 89.58 & 2 units & 179.16 & \\
\hline Unit & Equipment maintenance & 3.20 & 62.5 hours & 200.00 & \\
\hline Batch & Process receivables & 11.10 & 170 units & 1887.00 & \\
\hline Batch & Process Payable & 13.14 & 170 units & 2233.80 & \\
\hline Batch & Operate IT system & 1.03 & 2112 hours & 2175.36 & \\
\hline Batch & Prepare payroll & 12.50 & 18 persons & 225.00 & \\
\hline Batch & Process sales order & 14.43 & 100 units & 1443.00 & \\
\hline Facility & Training production personnel & 4.44 & 48 hours & 213.12 & \\
\hline Facility & Training on quality & 5.29 & 48 hours & 253.92 & \\
\hline Facility & Packaging training & 3.60 & 48 hours & 100.80 & \\
\hline \multicolumn{2}{|c|}{ Total non-remanufacturing activity cost } & & & 8732.00 & 582.13 \\
\hline \multicolumn{2}{|c|}{ Total crankpin cost per unit } & & & & 800.01 \\
\hline
\end{tabular}

Table 3.8 is show the cost per unit of crankshaft that belongs to MTU 183 engine model. The remanufacturing cost of this engine model is MYR 754.37 and non-remanufacturing cost of MYR212.15 and MYR542.22 respectively. There are altogether 15 units of crankshaft. The highest cost is spending in remanufacturing cost at program production is MYR 664.88. This is because program production is the key section of the state plan in a target for the sale and production to achieve a certain quantity output.

Table 3.8: Cost by ABC system from traditional inspection (MTU 183)

\begin{tabular}{|c|c|c|c|c|c|}
\hline $\begin{array}{l}\text { Activity } \\
\text { Level }\end{array}$ & Activity & $\begin{array}{c}\text { Cost per unit of } \\
\text { activity driver (MYR) }\end{array}$ & $\begin{array}{l}\text { Annual quantity } \\
\text { of cost driver } \\
\text { consumed }\end{array}$ & $\begin{array}{c}\text { Annual } \\
\text { cost (MYR) }\end{array}$ & $\begin{array}{l}\text { Cost per unit } \\
\text { of product } \\
\text { (MYR) }\end{array}$ \\
\hline Unit & Measure hardness & 10.40 & 15 units & 156.00 & \\
\hline Unit & Inspection process & 1.21 & 90 units & 108.90 & \\
\hline Unit & Grinding-machine hours & 0.67 & 175 hours & 117.25 & \\
\hline Unit & Grinding-setup hours & 0.73 & 285 hours & 208.05 & \\
\hline Unit & Polishing-machine hours & 0.70 & 95.6 hours & 66.92 & \\
\hline Unit & Polishing-setup hour & 0.53 & 240 hours & 127.20 & \\
\hline Unit & Cleaning-machine hours & 1.78 & 205 hours & 364.90 & \\
\hline Unit & Cleaning-setup hour & 0.88 & 250.6 hours & 220.53 & \\
\hline Unit & Perform leak testing & 1.04 & 110 hours & 114.40 & \\
\hline Unit & Polishing-machine hours & 1.19 & 60.5 hours & 72.00 & \\
\hline Batch & Program production & 0.25 & 2659.5 hours & 664.88 & \\
\hline
\end{tabular}




\begin{tabular}{|c|c|c|c|c|c|}
\hline Batch & Expedite order-grinding machines & 89.58 & 2 units & 179.16 & \\
\hline Batch & Expedite order-polishing machines & 89.58 & 2 units & 179.16 & \\
\hline Batch & Expedite order-cleaning machines & 97.73 & 2 units & 195.46 & \\
\hline Facility & Manage Plan & 9.25 & 15 units & 138.75 & \\
\hline \multicolumn{3}{|c|}{ Total remanufacturing activity cost } & & 3182.30 & 212.15 \\
\hline Unit & Equipment maintenance & 3.20 & 49.5 hours & 158.40 & \\
\hline Batch & Process receivables & 11.10 & 150 units & 1665.00 & \\
\hline Batch & Process Payable & 13.14 & 150 units & 1971.00 & \\
\hline Batch & Operate IT system & 1.03 & 2112 hours & 2175.36 & \\
\hline Batch & Prepare payroll & 12.50 & 18 persons & 225.00 & \\
\hline Batch & Process sales order & 14.43 & 90 units & 1298.70 & \\
\hline Facility & Training production personnel & 4.44 & 48 hours & 213.12 & \\
\hline Facility & Training on quality & 5.29 & 48 hours & 253.92 & \\
\hline Facility & Packaging training & 3.60 & 48 hours & 100.80 & \\
\hline \multicolumn{4}{|c|}{ Total non-remanufacturing activity cost } & 8133.30 & 542.22 \\
\hline \multicolumn{4}{|c|}{ Total crankpin cost per unit } & & 754.37 \\
\hline
\end{tabular}

Based on the result show in Table 3.9, the cost per unit of crankshaft that implement of MTS system is cheaper than the traditional system. So, it can prove that MTS is the best significant method to get more profitability.

Table 3.9: Cost per unit comparison among the engine models.

\begin{tabular}{|c|c|c|}
\hline \multirow{2}{*}{ Engine Model } & \multicolumn{2}{|c|}{ Cost per unit (MYR) } \\
\cline { 2 - 3 } & \multicolumn{2}{|c|}{ ABC System } \\
\cline { 2 - 3 } & Traditional (Type X) & MTS (Type Y) \\
\hline MTU 183 & 754.37 & 687.90 \\
\hline MAN & 800.01 & 738.13 \\
\hline
\end{tabular}

\section{CONCLUSIONS}

By implementing the MTS method, the classification of EOL crankshaft can be determined whether remanufacturable, rejected or repairable. The classification of EOL crankshaft are determined whether it can be remanufactured, repairable or rejected. Based on the result of inspection to identify the critical and non-critical parameters of both engine, Man engine model has 50\% critical crankpin and another 50\% belong to non-critical crankpin whereby, the MTU183 engine has 33\% critical crankpin and another $67 \%$ belong to non-critical crankpin diameter. Therefore, reducing the number of parameter can make the improvement of quality inspection. MTS has made a significant contribution to the final cost and ABC system has made a significant contribution to the selling price.

\section{ACKNOWLEDGEMENT}

The author would like to be obliged to University Malaysia Pahang for providing financial assistance under RDU170387.

\section{REFERENCES}

[1] Gray C. and Charter M. (2007). Remanufacturing and product design. Design for 7 Edition. 1-76.

[2] Feng, S., Hiroyuki, O., Hidennori, T., Yuichi, K. and Hu, S. (2011). Qualitative and quantitative analysis of gmaw welding fault based on mahalanobis distance. International Journal of Precision Engineering and Manufacturing. 12(6), 949-955.

[3] Matsumoto, M., Yang, S., Martinsen, K. and Kainuma, Y. (2016). Trends and Research Challenges in Remanufacturing. International Journal of Precision Engineering and Manufacturing-Green Technology. 3(1), 129-142.

[4] Pal, A. and J Maiti. (2010). Expert Systems with application Development of a Hybrid Methodology for Dimensionality Reduction in Mahalanobis-Taguchi System Using Mahalanobis Distance and Binary Particle Swarm Optimization. Expert Systems with Applications. 37(2), 1286-93.

[5] Ketkar, M. and Vaidya O.S. (2014). Evaluating and Ranking Candidates for MBA program: Mahalanobis Taguchi System Approach. Procedia Economics and Finance,11: 654-666. 
[6] Reséndiz, E., Moncayo-Martínez, L. A., \& Solís, G. (2013). Binary ant colony optimization applied to variable screening in the Mahalanobis-Taguchi system. Expert Systems with Applications, 40(2), 634-637.

[7] Reséndiz, E. and Rull-Flores C.A. (2013). Mahalanobis-Taguchi system applied to variable selection in automotive pedals components using Gompertz binary particle swarm optimization. Expert Systems with Applications, 40(2), 2361-2365.

[8] Li, C., Xiao, Q., Tang, Y. and Li, L. (2013). A method integrating Taguchi, RSM and MOPSO to CNC machining parameters optimization for energy saving. Journal of Cleaner Production, 135, 253275.

[9] Yang, T., and Cheng, Y-T (2010). The use of Mahalanobis-Taguchi System to improve flip-chip bumping height inspection efficiency. Microelectronics Reliability, 50(3), 407-414.

[10] Tsai, W-H (2013). A Product-Mix Decision Model Using Green Technologies under Activity-Based Costing. Journal of Cleaner Production, 57, 178-87.

[11] Tsai, W-H, Yang, C.H, Chang, J-C, Lee, H-L. (2014). An Activity-Based Costing Decision Model for Life Cycle Assessment in Green Building Project. European Journal of Operational Research, 238(2), 607-19.

[12] Emre, G.G., Bilir, S. and Sevim, M. (2015). Activity Based Risk Assessment and Safety Cost Estimation for Residential Building Construction Projects. Safety Science, 80(112), 1-12. 